Stream: Culture/Politics/Technology, 5(1): 8-20

http://journals.sfu.ca/cpt/index.php/stream/index

\title{
The Culture Apocalypse: Hegemony and the Frontier at the End of the World
}

Amanda Oldring

School of Communication, Simon Fraser University

\begin{abstract}
The turn of the millennium saw a marked increase in apocalypse-themed mass media, especially in television and film, of which the United States is the largest producer. The role of the apocalypse has been to produce hegemony for the ruling establishment that purported itself as being able to prevent or somehow save potential victims. Historically the church possessed this authority, but in contemporary society that role has been passed to governments and to scientific and technological institutions. In contemporary America, apocalypse is part of a spectrum of religious beliefs ingrained into the American Way of life. Commercial America has resurrected the apocalypse myth as spectacle commodity. Apocalyptic media today reflect current values of the American hegemon in globalization, and are portrayed as particularly real in order to be effective. The increased interest in disaster myths specifically reflects Beck's (1992) concept of a world risk society. Deconstructing the films Independence Day and The Day After Tomorrow reveals hegemonic devices that uphold the American way in the advent of globalization through the use of heteronormative values, scientific savior-adversary binaries, and symbolic rebirth through the recreation of frontier space.
\end{abstract}

\section{Keywords}

apocalypse, culture industry, simulacra, risk society, popular film

\section{Introduction}

The end of the world is the ultimate spectacle. The so-called Mayan apocalypse passed on December 21, 2012 without incident, as has every other doomsday prediction before it. Yet, the degree to which it was publicized astounds. Books, news reports, surveys, a plethora of cultural references, and even a feature film referred to it. Governments and institutions notably in Russia, China, and the United States responded by issuing formal statements denying or denouncing it (Barry, 2012; Evon, 2012; Kuo, 2012). Such reactions speak to a cycle of public anxiety, actual or perceived, perpetuated by this apocalypse spectacle in a reflexive society aware of its own mortality.

The terror and the glamour of global destruction captivate like little else. Baudrillard's (1994) simulacra and Ulrich Beck's (1992) world risk society provide paradigms for making sense of it. By deconstructing contemporary apocalyptic mass media within these frameworks the apocalypse spectacle is recognizable as an ideological device for the social institutions that perpetuate and consume it. Focusing on the United States as the world's largest consumer, this paper connects eschatology and the frontier myth to today's popular disaster films. In doing so, the hegemonic values concealed within them are made plain, and their impacts on the ideologies of globalization are revealed.

\section{Eschatology in the Simulacra}

Apocalypse has always been Christianity's contingency plan. Revelations states that those who follow the Bible's teachings will be raptured away during the second coming of Christ whilst nonfollowers perish during a great and violent cataclysm. Judgment Day extends the threat of Hell and the promise of Heaven to everyone. Survival, in the form of spiritual salvation, was guaranteed 
upon repenting sin. This ticket to the afterlife was redeemable for friends and family as well, but only if they followed suit. Such teachings perpetuated orthodox adherence to church doctrine at the group level via an ideology of fear and punishment avoidance psychosocialized as a shared utopian vision.

Baudrillard (1994) illuminated the hegemonic utility of end-time myths when he wrote, "We require (myths about) a visible past...which reassures us about our end, because finally we have never believed in them" (p. 392). Judgment Day proves "the real through the imaginary" (p. 396) by legitimating predestination through the negative; a predicted oblivion reifies a purposed, indisputable plan for humanity and by extension authenticates any social infrastructure that hinges upon it, like the Church. Thus, the apocalypse myth is teleology, scripted to validate its origins. Such myths help us fill, and avoid acknowledging, the void of their absence. We create them as a way to rationalize existence, but the cost is to sacrifice our agency to the invention. Its power stems from the fact that no one can be held responsible for it, just as its inevitability masks that intelligent design does not exist.

The myth "reinject(s) the real" (p. 397) into the institutions that uphold it. The more it is believed, the more authentic these establishments seem. Death is a fact of life, but mythologizing has killed it, elevating oblivion into the hyperreal of the simulacra where there is "no longer a Last Judgement to separate the false from true...(because) everything is already dead and resurrected in advance" (p. 390). As hyperreality, the apocalypse can be adapted to remain innocuous, and thus believable, over time. It no longer matters how it happens, as long as the way out remains. Escape is social currency and because the apocalypse deters its own dissolution by enforcing normative values, those who define the rules for and control access to escape obtain power simply by propagating the myth. The irony is that these arbitrary power dynamics are only sustained by mass belief. Thus the myths' legacy is that of the perpetual motion machine, a disaster scenario that is totally self-regulating and amounts to a total manipulation.

\section{Hegemony and the Façade of Religious Decline}

Antonio Gramsci theorized hegemony as "the indirect dominance of a society obtained through consent to intellectual and moral leadership, usually as imposed by the state" (Kellner \& Durham, 2012, p. 5). According to Gramsci (Kellner \& Durham, 2012, p. 5), hegemony is facilitated by the loose connection of social institutions that mediates between the state and the private/public spheres. Ideology, or the institutionalization of values and belief systems that produce and uphold the dominant social order, is a vehicle for hegemony in that it functions to manufacture consent for existing regimes.

Doomsday cults provide a working model for understanding how the apocalypse myth bolsters hegemony in contemporary North American culture. Both the Heaven's Gate and Jonestown massacres were preceded by a promised salvation in the wake of a constructed cataclysm. Each cult juxtaposed disaster against its unique knowledge about it, framing the cult as the one safe place to go. Adopting the cults' beliefs was required for survival. For instance, Heaven's Gate taught followers that human bodies were "merely a tool" that could be reissued when worn out (Heaven's Gate, 1997), a belief which ultimately provided a rationale for suicide. These values socialized follower dependency on the cult (Dein \& Littlewood, 2000). The more apocalypse ideology entrenched the cult's follower base, the more its leadership was reinforced.

Cult micro-societies demonstrate how power is legitimated through eschatological systems, just as mass suicides hold testament to the incredible extremes that people will consent to undergo. Ideology in mainstream culture is not nearly so explicit. Hegemony requires majority acceptance of what is inevitable or taken for granted as the perceived natural order (Hall, 1980, p. 143). Cultural artifacts are inherently ideological since they hold the views of their producers as well as the values of dominant social groups (Kellner \& Durham, 2012, p. 4). Myths, as one such artifact, are thereby 
mediums for hegemony. Indeed myths are particularly potent tools; their highest concern is to suppress individual experiences by supplanting them with archetypes of behavior and systems of meaning-making derived from and maintained in civil society (Campbell, 1990, p. 163). From a cultural studies perspective, artifacts form two aspects of civil society: the media and popular culture, which are interesting because of the growing volume of apocalypse-themed content they produce.

The key to deciphering and disempowering the apocalypse myth is exposing its context and benefactors. The crux of this issue is that a myth must be believed as true for the continuation of its power (Campbell, 1990, p. 71). However, while real power lives and dies, myths, as simulated realities, are immortalized and commercialized by social demands (Baudrillard, 1994). As commodities, myths possess economic values as saleable objects. They are a communicative resource and like any other resource they confer power to those who control access and dissemination within a population. "Selling" a myth is a matter of engendering belief as "buying" a myth is a matter of consenting to believe. In this way, cycles of myth production and consumption contribute to a collective narrative that justifies or explains a culture's existence to its own members, thus allowing power to self-perpetuate. Myth exchange between different classes thereby functions to uphold a hegemon by manufacturing consent to existing power regimes.

A circulating myth is invisible within the society that upholds it, and this makes it impossible to recognize the myth without a detecting method. One method proposed by previous literature is hermeneutic phenomenology. As American cultural historian Robert Darnton (1984) argues, abnormality creates transparent points of entry into a culture that can then be used to analyze and understand it. He writes, "when you realize you are not getting something - a joke, a proverb, a ceremony - that is particularly meaningful to the natives, you can see where to grasp a foreign system of meaning in order to unravel it" (p. 78). By using hermeneutic phenomenology to deeply scrutinize a cultural artefact from an outsider's perspective, it becomes possible to identify and deconstruct its semiotics in a reliable and replicable way. This in turn can be juxtaposed against similar artefacts within the mainstream to make their hegemonic utility apparent.

The reason why hegemonic processes are easily observed in cults is precisely because they are abnormal. Cults do not exist separately from the fabric of North American society but parallel to it. Baudrillard argues that Disneyland masks that North America is a fantasy (p. 393). In the same way, cults may conceal that Western culture is seduced by fatalism. By using cults as a point of entry, it becomes possible to identify the myth's basic processes and then to reflect these back onto mainstream culture. In both cult case studies, the promise of escape was used by those in power to purchase compliance to leadership as a means to avoiding a fabricated doom. This pattern is consistent with the Judgement Day myth, and the many post-millennial doomsday prophecies circulated in popular culture today. These can be understood as the myth's underlying structure. Having identified it, analysis now becomes a matter of locating fabricated disaster and escape patterns in popular culture and exploring how they perpetuate current ideologies.

To validate this process, it is necessary to also clarify why the apocalypse myth is important in the study of hegemony today. As post-Enlightenment views shifted from literal to symbolic interpretations of the Bible, the apocalypse myth presumably would have faded from popular discourse. Yet, given that one third of Americans believe rising natural disaster severity is a sign of the end-times (Public Religion Research Institute, 2012), it is reasonable to argue that something else is at play. Marx and Engels (1976) wrote, the "ideas (of the ruling class) are the ruling ideas of the epoch" (p. 32). Even in late capitalism, a successful hegemon secures complicity to the systems of production and distribution that define the class system maintaining it. When ideology is distributed as the natural order, alliances form that uphold current hierarchies (Althusser, 1971). De Tocqueville (1841) once argued: "religion ...by regulating domestic life...regulates the state" (p. 332). He felt that religion was so ingrained in the North American identity that fervor was stoked by nationalism and vice versa (p. 335). Bellah (1967) calls this phenomenon the cultural permeation of 
civil religion, or the religion of the American Way. It is so deeply instilled that worship is no longer needed (Hauerwas, 2011). One only need to read "In God We Trust" on an U. S. one-dollar bill to recognize religion still exists as part of the natural order today.

Recent empirical research suggests that exposure to religious activity positively correlates with religious beliefs across socio-economic statuses (Scheiman, 2010). New studies credit the relative power theory of religion, which states that the wealthy in unequal societies become more religious so that they can disseminate faith to pacify the impoverished class while maintaining their privileged status (Solt, Habel, \& Grant, 2011). Consequently, even though the United States legally separates church from state, and even though religiosity is generally on the decline as the standard of living increases (Solt et. al, 2011), the American Way embeds religious ideology into the cycles of supply and demand that run the country. Moreover, since economic inequality in North America is on the rise, it is feasible that cultural artefacts bearing American Way ideologies are also increasing as a means to pacifying the populace. Thus it is more likely that the apocalypse myth is on the rise in North American culture, but has been adapted to fit the ideologies of the day so as to remain opaque. If so, to meet with the rise in positivism, the apocalypse would need to come from an empirical and biophysical source, rather than divine. To exist within the contemporary neoliberal narrative, escape would need to be economic and political, rather than spiritual. This places the onus for the myth largely on scientific and technological institutions.

\section{Emancipation Spectacle}

Finally, where does apocalypse thrive if not in spectacle? Spectacles are commodities, dazzling arrays of contemporary institutional and technical apparatuses circulated through popular media events (Debord, 1977). Modern society has been saturated with spectacles. They occur in almost every social institution, in schools, churches, and politics, and their dissemination mediates perceptions of the world. Their greatest conduit is the media. Kellner (2005) argues that the modern spectacle enculturates individuals into its way of life through dramatized controversies and modes of conflict resolution (2). The spectacle is thereby the perfect host for myths, particularly ones about global destruction, which impact all demographics and captivate like little else.

The culture industry disseminates ruling ideologies to the masses through entertainment (Horkheimer \& Adorno, 1944). Produced by the wealthy and "denying its audience any dimension in which they might roam freely in imagination" (Horkheimer \& Adorno, 1944, p. 56), mainstream film, is a major conduit. Since visual codes "are the means by which power and ideology are made to signify in particular discourses" and as such are "the fragments of ideology" (Hall, 1980, p. 141), popular film is an ideal launch point into the modern apocalypse myth. Films are the ultimate larger than life spectacle, replete with big budget sounds, effects, writing and casting designed to dazzle an audience into a new reality. Because the apocalypse has been mythologized, its visual codes are highly flexible. As Bendle (2005) notes, any historical or current event can now signify the end of the world. If the wide variety of apocalyptic narratives in media spectacle to date is any indicator zombies, monsters, plagues, wars, aliens, supernova events, natural disasters, climate change, and energy crises to name a few - this would certainly seem to be the case.

Richard Langley (2011) notes that frontier ideology, which has been a part of American worldviews since colonization, has found a fertile ground for dissemination in apocalyptic cinema. Most of us recognize the frontier in the image of the Wild West. It is the edge of the known and the beginning of the unknown, a wild space, untamed, natural, and the home of the other archetype (King, 1999). It is the place people go when their current world order becomes unbearable, where law, order, and society have failed. The frontier promises rebirth and renewal, the chance to start over, and to do things right.

Of course, the frontier doesn't exist outside of ideology. Creating a new society indelibly requires overwriting something else. The environment must be tamed, and the other assimilated into the 
invading society's way of life or exterminated, as the European colonizers did to aboriginal societies in the New World. Hegemony accommodates the other by expanding its mythos to incorporate divergent populations in a fashion that maintains the dominant culture (Barthes, 1983, p. 97). Being unable to face the other, myth denies, assimilates, and mirrors it, thereby reducing it to sameness, just as mainstream media terminate it through promoting its demographics symbolically (Baudrillard, 1994, p. 391). Francis Lawrence's (2007) post-apocalyptic thriller I Am Legend, based on the 1954 book of the same name, provides a chief example. The protagonist, Neville, is the only surviving human and a scientist being capable of providing a cure to a world where a virus has turned the entire population into zombies. New York City has turned into a frontier space, replete with wilderness and feral animals. In the film, particularly in the alternate ending, the zombies demonstrate empathy, altruism for their own, and loyalty, particularly between the alpha male and the female he tries to rescue from Neville. Despite these attributes, the zombies in the film are dehumanized into an alienated population by their aggression and cannibalistic behavior. Denying the other's humanity morally justifies Neville killing them and using them for experimental purposes (Moya \& Lopez, 2013, p. 3). The film's theatrical ending shows the doors of a walled community opening to show a church, suggesting that although science has failed the world religion will redeem it (Moya \& Lopez, 2013, p. 3). Despite the fact that the human population is now a minority, Neville's antidote will allow it to both assimilate the other by curing the virus, and in the process to re-colonize the frontier with a new and better society with religion at the forefront. If nothing else, the film exemplifies how the apocalypse myth revives the permeation of civil religion in the American Way.

It is now generally accepted that the West's long history of colonizing so-called frontiers was both unjust and inhumane. Yet, to expand a hegemon frontier ideology requires the illusion of empty space. In an era of globalization, unpopulated space can only be achieved by destroying what already exists beyond memory or reparation. Hence the apocalypse myth is the frontier's greatest ally. An apocalypse equates to agentless global destruction, which provides a guilt-free void enabling ideological expansion anywhere and in any manner seen fit. The following three cases explore ideologies embedded within two apocalypse myth narratives, the Roland Emmerich's blockbusters Independence Day (1996) and The Day After Tomorrow (2006). Each case demonstrates how a frontier is created and used to legitimate current power structures. Religious ideology is rarely overt in either film, but both contain frontier ideology that employs fabricated disaster and escape mechanisms to justify dominant American power structures within the country and over other nations, as we shall see.

\section{Case One: Science will Save Me}

In today's apocalyptic media, technology is often framed as humankind's savior. For instance, Independence Day features global destruction through an alien war. As earth's technology is outmatched by aliens, all seems to be lost until American soldiers commandeer an alien craft and learn to fly it. The soldiers infiltrate the mothership, deactivate its shields with a computer virus, and destroy it from the inside using a nuclear bomb. Similarly, The Day After Tomorrow features a super storm caused by climate change that sweeps the world into a new ice age. The benefits of scientific progress and development are clearly displayed as high-tech survival gear allows the protagonists to persevere in extreme weather conditions, helicopters help rescue survivors, and climate science informs government decision making. In both films, technology is portrayed as a tool for redemption as well as a means of survival or escape from disaster.

How does this structure support hegemony? As Barthes (1983) has noted, a little confessed evil allows myths to obscure a lot of hidden evil (p. 96). In Independence Day, weapons of war are inversely portrayed as defenders of life when they turn an alien threat against itself. In doing so, the film acknowledges that nuclear bombs are weapons of mass destruction; yet, by portraying their 
capacity to stop a global enemy, using them is not only justified but also championed as a way to unify humanity. Portraying bombs in this light masks their global destructive potential. Similarly, The Day After Tomorrow frames American governance as profit-hungry, progress-blind, and shortsighted - a clear nod towards the country's refusal to acknowledge its contributions to accelerated climate change in the early 2000s. Yet, by the end of the film, when a contrite and sufficiently humbled vice president apologizes to his citizens, and then deploys the military to rescue surviving Americans, the audience is shown in no uncertain terms what the advantages of this system might be. The process overlooks that economic innovations such as the fossil fuel industry are largely responsible for the catastrophe in the first place. The emphasis is instead on technological determinism, wherein the destructive consequences of industrial society pale in comparison to the ability of technology to oust any antagonist, including a hostile environment.

In both films, a global disaster outside the control of any one person creates new physical and social frontiers by destroying existing infrastructure. Within this liminal space anything is possible, yet technology and science, despite their ills, are heralded as the way forward. As such, the established order is portrayed as the only and ultimately best solution. By perpetuating this sinsalvation dichotomy, these films ultimately reinforce ideologies of progress that underscore the systems of production and consumption that capitalism relies on, and by extension false consciousness. In other words, the realism injected into the narratives conceals their mythos, so disseminating misleading value systems amongst the public in the form of popular entertainment.

\section{Case Two: White Supremacist Patriarchy as Common Sense}

Another motif is the portrayal of Caucasian male dominance as fundamental to humanity. In both films, this naturalization is achieved through an agentless subversion of social equality that is facilitated by an apocalypse. It is well known that social equality in the private and public domains is disruptive to class-based societies simply because they rely on unequal hierarchical systems to function. A myth can maintain class systems by positing hierarchies as common sense and to this end will either deny or assimilate social equality so that the status quo remains unaffected. Heteronormativity is one such indirect hegemonic device; it privileges patriarchy through heterosexual relationships and gendered norms, strengthening hierarchies built on these values the way rebar strengthens concrete (Varela, Dhawan, \& Engel, 2011, p.16). White supremacy is another; it divides political, economic, and cultural systems such that a white minority appears entitled to them (Ansley, 1989, p. 1024). Both films privilege the subordination of females and nonwhites, the triumph of heterosexuality, and the emphasis on traditional marriage and family structures as requisites for some greater good. By doing so, the authority of a patriarchal and classbased civil society and by extension a capitalistic State is supported by structuring individual interactions within social institutions and with each other on a personal level. These interactions uphold a white-male ruling class by making social equalities that would otherwise be subversive to it appear ineffectual or less desirable during or post disaster. For example, in both The Day After Tomorrow and Independence Day "families, friendships and communities are simply depicted as the 'high stakes' for which the heroes are playing" (Bendle, 2005, para. 39). By doing so, these structures become victims waiting for rescue. Moreover, in Independence Day, a Jew teams up with an African American and Israeli forms an alliance with Palestinian, indicating a new level of social equality necessitated by a global threat (Wegner, 2009). Having a gay character as a key intellectual implies a normalization of alternative sexual orientations. There is also some attempt to reconcile the Madonna-whore complex that traditionally subjugates feminine identity into a binary controlled by the male gaze in the role of the female lead, who is both a stripper and a doting mother in a committed relationship.

Yet, these semblances of social equality are soon lost, leaving only traditional hierarchies intact. The (only) gay character is killed, literally and symbolically removing homosexuality from the new 
frontier. The hyper-sexualized female lead's conversation with the first lady shows that she is clearly embarrassed about being an exotic dancer. Embarrassment highlights the psychoanalytic threat and cultural taboo that explicit female sexuality has in a patriarchal society, reinforcing female subordination (Mulvey, 1992). Both mechanisms establish heteronormativity as natural and enduring and suggest that alternative social structures are less so. The deeds of the African American hero and the transnational alliances are enveloped within the United States' triumph as a global savior. Given that the president is a young, wealthy male Caucasian, his speech at the end of the film about a world Independence Day is wholly assimilationist (Langley, 2011). It implicates the American Way as the only means of escaping global annihilation. Inversely, this stance promotes universalizing the American Way, including white supremacy and heteronormativity, into a global monoculture.

The Day After Tomorrow is markedly similar. Its "high stakes" reiterate traditional gender roles of man as hero and woman as victim of fate, man as subject and woman as object of the male gaze. These are classic scopophilic applications of patriarchy (Mulvey, 1992). Laura's school performance shows her as being capable and highly intelligent. She is not overtly glamorous or sexualized, which demythologizes the role of a typical female lead and lends her greater mobility (Mulvey, 1992). However, her empowering traits are quickly subsumed. Shortly after the storm makes landfall, Laura gets cut and contracts severe blood poisoning. As the environment is the film's antagonist, this event places her into a victim role. At this point she becomes the motivational axis for the protagonist's son as he struggles to save her, assuming the mantle of primary love interest wherein her "eroticism is subjected to the male star alone" (Mulvey, 1992, p. 271). This point is further exemplified when two male rivals discuss who should woo Laura while actively watching her without her awareness, reducing her to object status. After her rescue, Laura's screen time and dialogue are drastically reduced. Her initial power prevents this objectification from being immediately obvious, likely because it is the disaster that strips her agency, not any character specifically. Patriarchy is not to blame because it is a victim as well. Yet, out of all possible social relations that could emerge in the new frontier, that traditional gender binaries survive when Laura's agency does not underscores the hegemony embedded in the plot.

The protagonist, Jack, also promotes heteronormativity through the myth of the noble-scientist, an altruistic idealist whose research is dedicated to the common good (Haynes, 2003). The noble scientist promotes internationalism, communal research, and open-source knowledge, directed only towards the betterment of society. The archetype is portrayed as wise enough to govern the entire world if needed yet a victim of immoral agents or forces of power that ignore or deny the character's knowledge. Jack's knowledge about the apocalypse is pitted against the US Vice President's promotion of economic progress and development. Jack wins, to everyone's detriment, yet his wisdom is rewarded. His scientific background allows him to save his loved ones and reunite his family against all odds, all while acting as the catalyst that sets American environmental policy to rights. The underlying message represented in his struggle is that environmental sustainability and the stability of the nuclear family are equally essential. Because they are yoked, proving environmental stewardship is necessary for global survival legitimates the nuclear family in the same way. And, since all leading characters are white, connections between heteronormativity and white supremacy within these constructs are further reinforced.

Cumulatively, each film employs the apocalypse myth to kill and so redeem the established order in two steps. First, by acknowledging alternative social constellations the established order appears to support progressive social equality. Second, an agentless apocalypse then annihilates these equalities along with the established order without making anyone responsible. Privileged heterosexual relationships and male over female and white over non-white hierarchies become the escape routes, and then the sole surviving relational structures in the new frontier. Through its death, the established order is separated from the relational hierarchies that support it. The survival of hierarchies created by white supremacist and heteronormative ideologies presents 
them as natural, universal, and biological, while masking the extent to which they are socially prescribed. Doing so promises to resurrect and so immortalize the established order. Thus, the apocalypse myth facilitates hegemony by celebrating a return to a global and eternal status quo.

\section{Case Three: This Land is Your My Land}

Finally, the apocalypse myth destroys the symbols of American culture only to resurrect them as universals. In both Independence Day and The Day After Tomorrow extreme adversity does not demolish the hegemon but bolsters it. Like relational hierarchies, cultural symbols are not antagonists but victims that engender sympathy and protection. The grand spectacle of their demise cries for their ideologies to be clung to and fought for all the harder.

A key example in The Day After Tomorrow features book burnings wherein atheists like Nietzsche are fed to the flames while the original King James Bible is preserved. Its protector is an academic who professes not to believe in God, yet argues the Bible warrants protection over other great works. This argument illustrates late Capitalism's fetishistic self-denial (Žižek, 1989, as cited in Treat, 2009), wherein "cynical reason, with all its ironic detachment, leaves untouched ...ideology [which] structures the social reality itself." (p. 103). Even the atheist is convinced of God's importance in the end. The apocalypse validates Christianity as universal by denying that it exists. Baudrillard (1994) calls this a spiral of negativity: power transformed into its' opposite to perpetuate itself in inverted form. Cynical reason denies religion, only to place it back on the bookshelf with new life and new supremacy in the same way that progressive social relationships in the previous section denied heteronormativity and white supremacy in the established order only to resurrect them in a stronger, globalized, and more enduring status quo. Scenes of a derelict Russian ship penetrating the flooded New York City, or the burying the Statue of Liberty in snow have similar effects. The monument's head and torch remain aloft; the new landscape makes the statue more accessible than it had ever been before the cataclysm. Characters can now walk up to Lady Liberty and look it in the eye. The statue peeking out amidst a vast and desolate wasteland becomes another inversion. No longer does the image represent the destruction of American concepts of freedom and democracy, but instead their revival; Liberty becomes a fire of resistance in the darkness of adversity, a testament to the endurance of the American Way, and a beacon of hope. Since America is now a new frontier, these intact ideologies are able to spread unhindered.

Langley (2011) illustrates how Independence Day's spectacle obliterates staunch American institutions - the White House, the Empire State building, the World Bank, and Capitol Records - in enormous and dramatic explosions. The act is the symbolic death of American government, national history, economy, and culture respectively. What is the significance of the concentrated obliteration of American symbols by an outside, unstoppable force? The overall impression is one of secularist narcissism, perhaps even wishful thinking. Given that the film was a blockbuster, a more pertinent question might be to ask: "why do audiences revel in seeing their societies destroyed?" The answer perhaps was stated first by Walter Benjamin (1969): our "self-alienation has reached such a degree that it can experience its own destruction as an aesthetic pleasure of the first order" (p. 49). By removing accountability from the equation, the apocalypse myth has been so distanced from subjective experience that it can be enjoyed as a symbolic cleanse over being perceived a potential threat.

Therefore, a two-fold effect is created by apocalyptic technospectacles. On the one hand, film markets better to its audiences if it includes familiar and culturally relevant images. On the other hand, disasters allow symbols to be reborn through their inversions and given greater power by expanding them beyond national boundaries. Thus, by victimizing and dramatically destroying American civil society to create a new frontier, the known evils embedded in these symbols, such as the West's long history of oppression, slavery, and colonialism, and the general malaise of rigid socioeconomic class divisions are simply erased. The frontier myth is liberating to those seeking to 
escape their current world order. In this sense destruction can be attractive. By erasing the past through global disaster, the West emancipates itself from both its social burdens and responsibilities. These symbols then become the focus of rebuilding and renewal without resistance or the weight of past mistakes. Rather than identifying systemic failures and changing these to build a better world, class-based society is instead symbolically exalted exactly as it was before the apocalyptic event, thus hegemonically ensuring its prolonged existence by disseminating the frontier myth without requiring the ruling class to relinquish any real power.

The frontier myth connotes ownership belongs to and is legitimated by the powerful (King, 1999). Consider the President's closing speech in The Day After Tomorrow:

"Not only Americans, but people all around the globe are now guests in the nations we once called the Third World...they have taken us in and sheltered us. And I am deeply grateful for their hospitality" (1:51:08).

Langley (2011) notes that the speech is reminiscent of the First Thanksgiving, suggesting that a new era of American expansion through frontier colonialism has begun. As the scene cuts to UH-60 Blackhawk helicopters in flight, the imagery certainly does privilege America's advanced agency compared to other developed and developing nations in the form of military might. If the medium is the message, audiences are receiving a bold reminder that the American hegemon legitimates itself as a helping nation in the global sphere, but a dominant nation nonetheless. Complicity to that hegemon is secured in myriad ways: through the triumph ideology in the symbolic order, the universalization of hierarchical social, gender, and racial divisions of power, and the globalization of a monoculture that values techno-industrial development characteristic of short-term resourcebased capitalism.

\section{World Risk Simulacra}

Beck (1992) argued that in the advent of globalization, the production of global risks and hazards has increased to the point that for the first time in history humanity faces the possibility of selfextinction. Two of the three hazards identified by Beck (2006) as dangerous to the entire planet are featured in the analyzed films: weapons of mass destruction in Independence Day and ecological collapse in The Day After Tomorrow. Their existence places humanity collectively, democratically, within a world risk society unified by the threat of extinction. The apocalypse myth is thus an ideological vehicle well suited for a risk society because its probability is also its appeal.

Beck (1992) argues that there is a direct relationship between the spread of a global capitalist monoculture and the production of global hazards, as the production of wealth is maximized by the production and transfer of risks. There is also a relationship between the production of risks and the production of social inequality, both within and between nations. If inequality explains the rising religiosity in North America, the cultural fascination with eschatological myths such as the apocalypse in modern form would be explainable. As demonstrated above, apocalyptic media disseminate the hegemonic values of American capitalism to both national and global audiences, so the apocalypse myth both connotes the values of world risk society, and also denotes American monoculture via emancipation.

Just as a World Independence Day does not hail an ultimate liberation but the overlay of an American monoculture onto everybody, The Day After Tomorrow creates a tabula rasa on which the American Way, idealized by the frontier, legitimized through military might and social conscience, becomes a civil religion that can be writ worldwide. Their survival as disaster advances is foremost privileged. The premise is that building a new, better, more peaceful world is the same as building an American world, and never mind the flaws. Through inversion helicopters become machines of peace, but their symbolic meaning as machines of war remains, a hegemonic tactic revealing "at 
every moment war and peace are equivalent" (Baudrillard, 1994, p. 403). A scenario of total pacification is the same as a one of total control.

Beck (1992) argues that the enormity and inevitability of risk society causes those afflicted to oscillate between fatalism and apathy, which further perpetuates the production of risks through lack of action. Thus, just as apocalypse ideology entrenched cult followers to comply with cult leadership, so too it can be argued the apocalyptic films function to entrench apathy and fatalism within collective audiences, culminating in the type of passive aesthetic pleasure that Benjamin envisioned as an alternative to action. If risk society strengthens wealth society, then fatalism and inaction are equally allies for the current hegemon. Therefore, apocalyptic cinema is not only world risk society's symptom, but also its metonymy. It is the manifestation of a society contemplating its mortality, yet that in doing so ironically functions to maintain the existing hegemon spiraling it towards that end in the first place. World risk society is therefore also simulacra: "the social itself that, in contemporary discourse, is organized along the lines of a disaster-movie script." (Baudrillard, 1994, p. 406).

The Day After Tomorrow's final scene is from space. Two astronauts look on a new earth covered in ice. There are no lights, no signs of industry. It is a cold, pure, even virginal, space. The film ends with one astronaut asking the other, "Have you ever seen the sky so clear?" Through apocalypse the deadlock of world risk society has been destroyed. The atrocities of colonialism, genocide, the classsystem, and industrialization, of society itself are all gone. There is no longer a need to repair them, or compensate for them. The collective sins of the West have been wiped clear along with their collective guilt. That no one is responsible conceals that everyone is. Apocalyptic media is the fetishistic deterrence of power. By making the end of the world agentless, the systems that propel its possibility forward are able to continue unchecked.

\section{I, Zombie}

Beck (2006) argues that the only way to break the political deadlock of a world risk society is to cosmopolitanize, to bring in transnationally representative change from the bottom-up through the creation of political vacuums and the sub-political interference of international publics. Without such a system we are limited to fluctuations between fatalism and apathy in the face of global cataclysm. Furthermore, Baudrillard (1994) states: "Capital...is a challenge to society...a challenge to take up according to symbolic law" (p. 395). In essence, he argues that the arbitrary cessation of negative inversions and resurrections of power through deterrence is the only way that political reality can be redeemed. Because attacking the illusion of power validates and so resurrects it continuously, cessation of power cannot be a deliberated, conscious effort. Rather, it must occur unconsciously, arbitrarily, so as not to perpetuate power. Arbitrary cessation can therefore be obtained through transnational symbolic resistance. To this end, one apocalyptic symbol is immediately of interest: the zombie.

The earliest history of zombies in North America comes from Haitian slavery. Zombies violate the strictest taboos about the body: cannibalism and the divide between life and death. A zombie was a slave who was denied freedom to return to Africa after death (Wilentz, 2012). Instead, a zombie was neither alive nor dead; it had no free will. It was condemned to do the bidding of its master forever, a slave for eternity. Over the years there have been many adaptations of the zombie, and many an apocalyptic narrative dedicated to it, but the terror inspired by eternal slavery to unbearable conditions persists. Today's zombies reflect fears of pandemic infection, untrustworthy authority, and the total collapse of social order (Ozog, 2013), not to mention the total loss of humanity to insatiable violence and hunger. However, what is most interesting about the zombie is that it has replaced almost every other monster in popular culture. The years between 2000 and 2010 have been marked by recent spike in zombie appearances. The Walking Dead is the most watched drama in basic cable television history (AMC, 2013) and Resident Evil is a billion dollar 
franchise. It is said that every generation has a monster that embodies its deepest fears; if so, and if popularity holds any weight, the monster belonging to post-millennial America is without question the zombie.

Zombies are risk society's mascot, a symbol of a self-reflexive society aware of its ability to selfdestruct. This makes the recent popular interest in zombie-walk flash mobs a particularly fascinating phenomenon. Thousands of people gather dressed as the undead to replicate a zombie apocalypse. Given the parallels between social interest in the zombie and the rising fiscal inequalities in America today, zombie events certainly merit further semiotic analysis. The author's opinion is that by symbolically becoming the monster, those who dress as zombies not only enjoy the aesthetic of self-obliteration but also recognize, although perhaps not consciously, that their current world order is not working and that there is nothing in place to fix it.

Therefore, those who participate in social protest in the guise of zombies act as a stark warning that the end result of their current world order is not a frontier, but a wasteland. If so, the zombies that crop up at gatherings such as Occupy Wall Street and Idle No More, and the recurrence of slogans such as "Eat the Rich" at these events may be more culturally significant than they are typically given credit for. Rather they are a form of symbolic protest. Since the zombie is a symbol of social decay, donning that symbol acts to embrace that reality, and so arbitrarily cuts at the systemic failures that create the symbol in the first place. It uses Debord's spectacle commodity paradigm against itself to incite social change instead of strengthening hegemony. In doing so, it is possible that transnational participation in symbolic protest against risk society and the escalating wealth production and social inequalities it produces may impact power on a symbolic level. Zombies may incite the arbitrary cessation needed to deter or impede current power structures, if only by inciting increased awareness of their functions.

In sum, research into the semiotics of apocalypse-themed protest, particularly when it appears arbitrary and spontaneous in the context of larger transnational movements, may provide better leverage into understanding whether Beck and Baudrillard's paradigms explain the production of hegemony in a risk society. More to the point, such work will provide greater insight as to the ways in which symbolic protest subverts power without inversely reifying it through denial, and so whether these models can be applied to incite positive social change. These points present a strong case for why studying apocalypse semiotics in critical activism is relevant today. Such work may also uncover other tactics that accomplish the reinstatement of hegemony in apocalyptic cinema. The apocalypse myth comes in myriad forms, and there is no one unifying interpretation. Yet, it should by now be clear that its underlying structure appears consistently across variations and that this structure functions to legitimate an existing hegemon by reinforcing social structures through idealized escapes. Tantamount to this discovery is to recognize that removing myths of inevitability and immobilization, as well as myths that maintain damaging hierarchies by neutralizing change, is entirely necessary, as these ultimately uphold risk society and the systems of capital that promote it. The apocalypse myths in the films explored in this paper are only one place to start. By recognizing and revealing these myths wherever they occur, we may disempower them. It is only by exposing the simulacra within our shared reality that it can be identified and, perhaps, consciously manipulated towards a risk preventative society, instead of one that delights in watching its own suicide.

\section{References}

Althusser, L. (1971). Ideology and ideological state apparatuses (Notes towards an investigation). In D. Kellner \& M. G. Durham (eds.), (2012). Media and cultural studies: Key works (pp. 80-86). Oxford, UK: Wiley-Blackwell.

AMC. (2013). The walking dead. Retrieved from: http://www.amctv.com/shows/the-walkingdead/about 
Ansley, F. L. (1989). Stirring the ashes: Race, class and the future of civil rights scholarship. Cornell Law Review, 74, 992-1067.

Barry, E. (2012, December 1). In panicky Russia, it's official: End of world is not near. The New York Times. Retrieved from http://www.nytimes.com/2012/12/02/world/europe/mayan-end-ofworld-stirs-panic-in-russia-and-elsewhere.html?pagewanted=1\&_r=3\&

Barthes, R. (1983). Myth today. In Mythologies (A. Lavers, Trans.). New York: Hill and Wang. (Original work published 1957)

Baudrillard, J. (1994). The precession of simulacra. In D. Kellner \& M. G. Durham (eds.), (2012). Media and cultural studies: Key works (pp. 388-406). Oxford: Wiley-Blackwell.

Beck, U. (1992). On the logic of wealth distribution and risk distribution. In U. Beck, Risk society: Towards a new modernity (1st ed.). London, UK: Sage Publications.

Beck, U. (2006). World risk society as cosmopolitan society?: Ecological questions in a framework of manufactured uncertainties. Theory, Culture \& Society, 13, 1-32.

Benjamin, W. (1969). The work of art in the age of mechanical reproduction. In D. Kellner \& M. G. Durham (eds.), (2012). Media and cultural studies: Key works (pp. 37-53). Oxford: WileyBlackwell.

Bellah, R.N. (1967). Civil religion in America. Daedalus, 134, 40-55.

Bendle, M.F. (2005). The apocalyptic imagination and popular culture. Journal of Religion and Popular Culture, 11, n.p.

Campbell, J. (1990). The flight of the wild gander: Explorations in the mythological dimensions offairy tales, legends, and symbols. New York: HarperCollins Publishers.

Darabont, F., Hurd., G.A., Alpert, D., Kirkman, R., Eglee, C.H. \& Mazarra, G. (2010). The walking dead [Television series]. United States: AMC.

Darnton, R. (1984). The great cat massacre and other episodes in French cultural history. New York: Basic Books Inc.

Debord, G. (1977). The commodity as spectacle. In D. Kellner \& M. G. Durham (eds.), (2012). Media and cultural studies: Key works (pp. 107-109). Oxford, UK: Wiley-Blackwell.

De Tocqueville, A. (1841). Democracy in America. (H. Reeve, Trans.). New York: J \& H.G. Langley. (Original work published in 1838).

Dein, S. \& Littlewood, R. (2000): Apocalyptic suicide. Mental Health, Religion \& Culture, 3:2, 109-114.

Devlin, D. (Producer), \& Emmerich, R. (Director). (1996). Independence Day. United States: Columbia Pictures.

Evon, Dan. (2012, December 13). Millions of Americans believe the world will end on December 21, 2012. The Inquisitr. Retrieved from http://www.inquisitr.com/437654/millions-of-americansbelieve-world-will-end-on-december-21-2012/

Gordon, M. (Producer), \& Emmerich, R. (Director). (2004). The Day After Tomorrow. United States: $20^{\text {th }}$ Century Fox.

Hall, S. (1980). Encoding/Decoding. In D. Kellner \& M. G. Durham (eds.), (2012). Media and cultural studies: Key works (pp. 137-144). Oxford, UK: Wiley-Blackwell.

Horkheimer, M. \& Adorno, T.W. (1944). In D. Kellner \& M. G. Durham (eds.), (2012). Media and cultural studies: Key works (pp. 53-75). Oxford, UK: Wiley-Blackwell.

Heaven's Gate. (1997). Heaven's gate away team returns to level above human in distant space. Retrieved from http://www.heavensgate.com/misc/pressrel.htm

Hauerwas, S. (2011, August 8). Best of 2011: The death of America's God. ABC Religion and Ethics. Retrieved from http://www.abc.net.au/religion/articles/2011/08/08/2947368.htm

Haynes, R. (2003). From alchemy to artificial intelligence: stereotypes of the scientist in Western literature. Public Understanding of Science, 12, 243-253. doi: 10.1177/0963662503123003

Kellner, D. (2005). Media culture and the triumph of the spectacle. In Media Culture (1). London: Routledge. Retrieved from http://pages.gseis.ucla.edu/faculty/kellner/papers/medculturespectacle.html 
Kellner, D. \& Durham, M.G. (2012). Adventures in media and cultural studies: Introducing key works. In D. Kellner \& M. G. Durham (eds.). Media and cultural studies: Key works (pp. 1-23). Oxford, UK: Wiley-Blackwell.

Klosner, H., Gordon, M., Franco, L.J. (Producers), \& Emmerich, R. (Director). (2009). 2012. United States: Columbia Pictures.

King, G. (1999). Spectacular narratives: Twister, Independence Day, and frontier mythology in contemporary Hollywood. Journal of American Culture, 22, 25-40.

Kuo, Li. (2012, December 20). In China, government's denial of Mayan apocalypse is only fueling paranoia. Quartz. Retrieved from http://qz.com/37958/in-china-governments-denial-of-mayanapocalypse-is-only-fueling-the-paranoia/

Langley, R. (Producer and Director). (2011). American Un-Frontiers: Universality \& Apocalypse Blockbusters. American Frontiers [Video Essay Conference Proceedings]. Retrieved from http://americanfrontiers.co.uk/?portfolio=richard-langley

Marx, K. \& Engels, F. (1976). The ruling class and the ruling ideas. In D. Kellner \& M. G. Durham (eds.), (2012). Media and cultural studies: Key works (31-33). Oxford: Wiley-Blackwell.

Moya, A. \& Lopez, G. (2013). Border poetics and the 'third space' in I am legend (Francis Lawrence, 2007), the road (John Hillcoat, 2009) and the book of Eli (The Hughes Brothers, 2010). Interdisciplinary.net. Retrieved from: http://www.inter-disciplinary.net/at-the-interface/wpcontent/uploads/2013/08/moyasafpaper.pdf

Mulvey, L. (1992). Visual pleasure and narrative cinema. In D. Kellner \& M. G. Durham (eds.), (2012). Media and cultural studies: Key works (pp. 267-274). Oxford: Wiley-Blackwell.

Ozog, C. A. (2013). Fear rises from the dead: A sociological analysis of contemporary zombie films as mirrors of social fears. Unpublished Doctoral dissertation, Faculty of Graduate Studies and Research, University of Regina. Retrieved from: http://ourspace.uregina.ca/bitstream/handle/10294/3811/Ozog_Cassandra_Anne_200243342 _MA_SOC_Spring2013.pdf?sequence=1

Public Religion Research Institute. (2012). Survey | Americans more likely to attribute increasingly severe weather to climate change, not end times. Public Religion Institute. Retrieved from http://publicreligion.org/research/2012/12/prri-rns-december-2012-survey/

Scheiman, S. (2010). Socioeconomic status and beliefs about God's influence in everyday life. Sociology of Religion, 71, 25-51.

Solt, F., Habel, P., \& Grant, J. T. (2011). Economic inequality, relative power, and religiosity. Social Science Quarterly, 92(2), 447-465.

Treat, S. (2009). How America learned to stop worrying and cynically ENJOY! The post-9/11 superhero zeitgeist. Communication and Critical/Cultural Studies, 6, 103-109.

Varela, M., Dhawan, N., \& Engel, A. (2011). Hegemony and heteronormativity: Revisiting the 'political' in queer politics. United Kingdom: Ashgate Publishing Limited.

Wegner, P.E. (2009). "A nightmare on the brain of the living": Messianic historicity, alienations, and Independence Day. Rethinking Marxism: A Journal of Economics, Culture \& Society, 12, 65-85.

Wilentz, A. (2012, October 30). A zombie is a slave forever. The New York Times: The Opinion Pages. Retrieved from http://www.nytimes.com/2012/10/31/opinion/a-zombie-is-a-slaveforever.html?_r=0

Žižek, S. (1989). The sublime object of ideology. London: Verso. 